\title{
Current Complexities of English Teaching in Costa Rica ${ }^{1}$
}

\section{(Aspectos actuales de las complejidades de la enseñanza del inglés en Costa Rica)}

\author{
Henry Sevilla Morales² \\ Universidad Nacional; Universidad de Costa Rica, Costa Rica
}

\begin{abstract}
Current complexities of English teaching in Costa Rica's public secondary education are discussed. Using an autoethnographic research approach, critical incidents of an EFL teacher are examined in light of Complexity Theory. Findings suggest that classrooms are unpredictable sites of struggle where multiple rationalities coexist (and often conflict), which must be understood before random decisions are made. For applied linguistics, the study is relevant at three levels: it expands the bulk of literature on the subject, it calls for more attention to the complexities of EFL, and it opens an avenue for reflection and future research directions.
\end{abstract}

\section{RESUMEN}

Se analizan ciertos aspectos de las complejidades actuales sobre la enseñanza del inglés de secundaria en la educación pública de Costa Rica. Mediante la autoetnografía, se analizan incidentes críticos de un docente de inglés como lengua extranjera, a la luz de la teoría de la complejidad. Los hallazgos indican que el aula es un espacio de enfrentamientos entre las distintas racionalidades que coexisten, que deben comprenderse ante cualquier toma de decisiones. El estudio atiende tres aspectos: expande la bibliografía sobre el tema, resalta las complejidades de la enseñanza de

1 Recibido: 6 de febrero de 2017; aceptado: 15 de mayo de 2017. Article based on a paper presented at the V Congreso Internacional de Lingüistica Aplicada (V CILAP), Oct. 5, 6 and 7, 2016 (Universidad Nacional, Campus Omar Dengo, Heredia, Costa Rica).

2 Escuela de Literatura y Ciencias del Lenguaje (UNA); Escuela de Lenguas Modernas (UCR). Correo electrónico: henrysevilla@gmail.com 
lenguas extranjeras y abre espacios de reflexión y rutas para investigaciones futuras.

Keywords: teaching English as a foreign language, Complexity Theory, autoethnography

Palabras clave: enseñanza del inglés como lengua extranjera, teoría de la complejidad, autoetnografía

\section{Some Initial Considerations}

It is with a good dose of concern, but also with a rush of urgent relief, that I venture to write an article whose validity could be met with downright skepticism in the contours of current academia. I acknowledge this possibility on the basis of two facts. The first is that my modest contribution cannot fully problematize the far-reaching complexities of the issue at hand (i.e., English teaching in Costa Rica). The second is that the methodology I have chosen (i.e., autoethnography) is every so often frowned upon by advocates of positivistic approaches to educational research, ${ }^{3}$ perhaps because it openly embraces subjectivity ${ }^{4}$ and thus abandons the traditional cannons of knowing where reality is understood as a continuum of observable, measurable variables under the researcher's control. But even so, it is my hope to create an avenue for reflection on an issue that, to this date, prompts much discussion but inspires little writing.

In the context of Costa Rica's educational landscape, it is not uncommon to hear the open accusation that students' failure to master basic language skills in English is the result of inadequate teacher preparation and faulty methodological choices. On close examination, this claim carries within it the premise that quality education is the sole responsibility of teachers, and that other contextual and individual variables play little or no role in the learning experience. Although

3 A. Suresh Canagarajah, "Teacher Development in a Global Profession: An Autoethnography," TESOL Quarterly 46, 2 (2012): 258-279 (260). DOI: https://doi.org/10.1002/tesq.18

4 Dwayne Custer, "Autoethnography as a Transformative Research Method," The Qualitative Report 19 (2014): 1-13. 
very common, this assertion is hardly based on scientific evidence but rather tossed around through word of mouth and popular belief. One major pitfall with this type of reasoning is that it is often the basis for high stakes decision-making, such as Costa Rica Multilingüe, ${ }^{5}$ where large sums of money are invested on teacher training ${ }^{6}$ to deal with a problem that, from the theoretical standpoint of this paper, is rooted in elements beyond the exclusive reach of teachers.

Thus, in an attempt to call for fairness on the subject, as well as to create room for reflection and research-informed decision-making, this study examines a string of critical incidents (CIs) that illustrate the hurdles behind English teaching in public high schools of Costa Rica in light of the principles of Complexity Theory (CT). Along these lines, I hope to honor the voices of actual teachers who have experienced the clash between theoretical precepts and the teaching realities of their classrooms.

\section{From the Methods Explosion to Ethical-Philosophical Concerns: A Brief Historical Overview}

Tracing the birth of teaching approaches is probably as elusive a task as tracing the origins of Applied Linguistics itself. Nevertheless, we can speak with some confidence about an explosion in teaching methods in the $20^{\text {th }}$ century ${ }^{7}$ more specifically after the establishment of the Council of Europe's Modern Language Project, ${ }^{8}$ which would mark the beginning of an era of language education. According to Ian Tudor, the increasing interest in the subject from the 1960s on arose because many colonial empires had started to disappear. Many new

5 Presidencia de la República [de Costa Rica], "Costa Rica Multilingüe," Ente Rector del Plan Nacional de Inglés (2009) 1-15.

6 For further reference on these investments and government efforts, see: Allen Quesada. "La enseñanza y aprendizaje del idioma inglés: la investigación y su impacto en la realidad costarricense," Revista de Lenguas Modernas 19 (2013): 393-408.

7 See Sherry E. Gapper, “¿Adónde vamos y de dónde venimos en Lingüística Aplicada?,” Letras 53 (2013): 137-154.

8 For further detail, see: Phil Benson, Teaching and Researching Autonomy (New York: Pearson Education, 2013) 9. 
countries which had recently obtained their independence began to invest more in education, and this in turn led to the need for knowledge of foreign languages, especially of English. ${ }^{9}$ These changes brought about pedagogical implications that were evident in two ways. They "increased the demand for language teaching [on the one hand], and they altered the nature of this demand" on the other ${ }^{10}$. Now language was conceived as fulfilling an array of practical functions such as traveling, ability to read specialized material, development of oral skills in a given field of economy, all of which required basic communication skills. Based on these demands, several approaches emerged, producing a boom in teaching methodologies and advancements in teaching materials and the expansion of research journals. In many ways, this proliferation could be compared to the progress made by other disciplines such as math or medicine through centuries of empirical research and exploration, but this has been a double-edged sword. In a short period of time, we have gone from the Audio-Lingual Method to Suggestopedia; from the Silent Way to Total Physical Response; and from the Natural Approach to the Communicative Approach (most recently referred to now as "Communicative Approaches," to include a number of other communicative-based methodologies). ${ }^{11}$ With such a vast range of approaches at hand - the newest often contradicting the former - it is no surprise that teaching professionals feel rather perplexed by what is supposed to have brought practical orientations to their everyday classroom challenges. Theoretically at least, today language education can be placed within the chronology of what some have termed the Post-Method Era, ${ }^{12}$ a period of deep renewal in the

9 Ian Tudor, The Dynamics of the Language Classroom (Cambridge: Cambridge University Press, 2001) 5-6.

10 Tudor, 6.

11 Hanizah Zainuddin, "Methods/Approaches of Teaching ESOL: A Historical Overview," Fundamentals of Teaching English to Speakers of Other Languages in K-12 Mainstream Classrooms, $3^{\text {rd }}$ ed. (Dubuque, Iowa: Kendall/Hunt, 2011) 63-74.

12 Douglas H. Brown, "English Language Teaching in the 'Post-Method' Era: Toward Better Diagnosis, Treatment, and Assessment," J. C. Richards and W. A. Renanyda, eds., Methodology in Language Teaching (New York: Cambridge, 2002) 9-18. 
way we understand teaching methods and their relevance for classroom application. And while many of us would agree that methods-based teaching is obsolete and should therefore be abandoned, evidence from recent research allows to infer that in Costa Rica: (1) for many teachers, this type of instruction is an everyday concern, (2) our public education system continues to enforce methods-based pedagogy through the Communicative Approach, and (3) some researchers themselves seem also to support this view as a way to meet current communication demands in English. ${ }^{13}$ Still at the theoretical level, in the past few decades research has experienced a shift in focus from methodological matters to more ethical and philosophical issues that have given raise to yet other pedagogies such as Culturally Responsive Teaching ${ }^{14}$ or the Pedagogy of Love. ${ }^{15}$

In Costa Rica, examples of this shift are best represented by (but not limited to) authors such as Luis Barrantes, ${ }^{16}$ Christian Fallas, ${ }^{17}$ Olga Chaves, Ana Solano, and Nuria Villalobos, ${ }^{18}$ all of whose works stress a growing concern with subjects beyond the technical elements of language instruction. In "Teaching and Learning in Costa Rica: A Critical Approach," Emory University scholar Ana Solano calls for a view beyond the pragmatic perspective that defines English teaching as serving a merely "linguistic and communicative function." 19 She

13 Catalina Domian Sánchez, Hilda Fonseca Solórzano, Rocío Lara Jiménez, and Sonia Rodríguez Salazar, "La enseñanza comunicativa del inglés en el ciclo diversificado en Costa Rica: imágenes de algunas realidades," Letras 47 (2010): 11-34.

14 Ebony Elizabeth Thomas, "Dilemmatic Conversations: Some Challenges of Culturally Responsive Discourse in a High School English Classroom," Linguistics and Education 24, 3 (2013): 328-347. DOI: https://doi.org/10.1016/j.linged.2013.03.004

15 See: Antonia Darder, Reinventing Paulo Freire: A Pedagogy of Love (Boulder: Colo: Westview Press, 2002).

16 Luis Guillermo Barrantes, "Formación de nuevos docentes y educación continua para docentes en servicio: su aporte a la justicia social," Letras 57 (2015): 179-194.

17 Johanna Ennser-Kananen, Christian Fallas Escobar, and Martha Bigelow, "It's Practically a Must: Neoliberal Reasons for Foreign Language Learning," International Journal of Society, Culture \& Language, in press (2016).

18 Olga Chaves Carballo, Ana Solano Campos, and Nuria Villalobos Ulate, "In the Search for Social Justice: Implementing Critical Pedagogy in the Language Classroom," Linguagem \& Ensino 13, 2 (2010): 415-434.

19 Ana Solano Campos, “Teaching and Learning English in Costa Rica," Letras 52 (2012): 163-178 (165). 
explains that current efforts to keep English teaching at the forefront of educational advancements center for the most part on "pedagogical and linguistic elements, with ideological considerations being kept at the margin $[\ldots]^{\prime 20}$; implying that ignoring the need for critical perspectives in English instruction and in education at large is a luxury that we simply cannot afford. To take our first steps toward critical pedagogy, the author recommends Alastair Pennycook's Unifying Themes for a Critical Approach to TESOL, which focus on "issues of class," "forms of difference," and "forms of critical theory" to help learners ponder the social makeup of their environments, and engage in "constant skepticism, questioning about the types of knowledge, theory, practice, or praxis." ${ }^{.1}$ The author calls for a need to modify curricular contents via incorporating authentic materials that outline various issues of social justice if Pennycook's framework is to be used, and provides a list of online resources as a way to approximate this type of critical pedagogy inEFL. Among her conclusions, she proposes as a first step that current teacher preparation curricula be modified to "include opportunities for instructors and students to develop skills for the critical analysis of reality, and in this case in particular, of our linguistic reality." 22 She also advocates the use of "historical thinking, transdisciplinarity, and comparative perspectives of social justice issues into their lessons" to break away from the materialistic perspectives that often dictate language education agendas. ${ }^{23}$

Luis Barrantes has recently published two articles that advocate for English teaching that caters to social justice and welfare beyond the technicist philosophies already outlined in critical pedagogy. In the first article, about training teachers in issues related to social justice, Barrantes is critical of current gaps between the rich and the socially-disadvantaged, which, in his opinion, are rooted in the lack

20 Solano, 169.

21 Solano, 171.

22 Solano, 177.

23 Solano, 177. 
of opportunities experienced by youngsters in Latin America's educational systems. ${ }^{24}$ According to the author, the only way to bridge these inequalities is to empower future teachers to become agents of change through a gradual shift of epistemological paradigms and worldviews. More than learning about teaching methods, today's English teachers need to be equipped with the flexibility to make general theories work locally for their own populations. ${ }^{25}$ Throughout the rest of the article, the author goes on to propose certain stages that will eventually lead educators to transform the social realities around them and to ultimately reach human liberation. In the second article, related to the need to establish a bridge between theories of language acquisition and social justice, ${ }^{26}$ Barrantes proposes an emancipatory model to challenge the status quo of current Second Language Acquisition Theory (SLAT) where language instruction is based on the money-making trends dictated by the Western world's "globalization-oriented paradigm." 27 He argues that today's current foreign language teaching contributes little or nothing to social justice, pushing students into believing that learning English will guarantee the social status validated by the neoliberal model.

Still another author, Christian Fallas, has published several articles where all of the anti-technicist ideas for language learning discussed above seem to converge. His most recent publications, all of them research papers, criticize many commonly-held assumptions about English teaching and learning in Costa Rica and elsewhere to ultimately recommend joining efforts to "broaden the spectrum of FL motivations for the benefit of more successful and more equitable

24 Barrantes, "Formación...," 181.

25 Barrantes, "Formación...," 182.

26 Luis Guillermo Barrantes, “¿Cómo establecer un puente entre la teoría de adquisición de segundas lenguas y la justicia social?," Letras 57 (2015): 195-212.

27 Barrantes, “¿Cómo establecer...," 195. 
language learning experiences"28 — a claim that can also be found in one of Fallas' earlier articles." 29

By and large, the problems of de-legitimizing the total value of English through reductionist language teaching agendas might not seem so obvious at first sight. However, careful examination of recent research helps establish connections between this tendency and overall impoverishment of social welfare. From a critical standpoint, diminishing language exclusively to linguistic competence is a first step away from the social well-being that is the birthright of every good education. Too much a diet of language command through banking education, as Paulo Freire terms it, where the learner uncritically receives the dogmas of a 'superior' agent called the teacher, leaves little or no room for the cultivation of higher order thinking skills, and much less for fostering other crucial elements of holistic education such as personal growth, creativity, spirituality, motivation, and "individual freedom and responsibility," as Chaves, Solano and Villalobos argue. ${ }^{30}$ This is, in our opinion, where real failure begins.

Currently, neoliberal policies seem to be responsible for the Costa Rican government's reduction of socially-oriented projects initiated decades before the 1980s because the emphasis is on preserving economic steadiness. David Shiman explains that, according to the National Council of Chancellors (Consejo Nacional de Rectores), "Costa Rica has cut back on social investments to maintain fiscal equilibrium and prevent further risks to economic stability." ${ }^{31}$ This restructuring in investment schedules arguably triggers a vicious cycle where economic interest takes precedence over socially-committed education, and where education in turn becomes a tool to perpetuate the technicist mentality of the neoliberal model. So far, English teaching

28 Ennser-Kananen, Fallas, and Bigelow, in press.

29 Christian Fallas, "Challenging the Monolingual Bias in EFL Programs: Towards a Bilingual Approach to L2 Learning," Revista de Lenguas Modernas 24, 1 (2016): 249-266.

30 Chaves, Solano, and Villalobos, 421.

31 Davis Shiman, "Human Rights Education in Costa Rica: More Expectation than Implementation," Revista Interamericana de Educación para la Democracia (RIED) 2, 1 (2009): $31-51$ (47). 
programs in Costa Rica's public education system have focused mainly on developing linguistic competences. This has incidentally left other crucial dimensions of language education relegated to second and third place. We are yet to confirm whether forthcoming versions of English curricula will reach a better balance between the many elements that according to the literature reviewed should be considered in all program development.

\section{Theoretical Lens and Methodology}

The current research is based on three CIs that took place at some point between 2012 and 2014. They are analyzed from a CT perspective to understand their complex, multifaceted nature..$^{32}$ This is done through the methodological principles of autoethnography, complemented by introspective research techniques such as journal writing, free writing, and autobiographical writing. Although epistemologically compatible, theoretical perspective and methodological lens do not mean the same thing. The former is "the philosophical underpinning that provides a context for the research process to occur locally, whereas the latter is a plan of action." ${ }^{33}$ In this paper, CT is a way of knowing; a conceptual framework to theorize about the critical incidents. Autoethnography is the vehicle (i.e., the methodological tools) used to put the pieces together for the narration of the CIs.

According to Canagarajah, the best way to understand the construct of autoethnography is to break it down into its smaller components: auto, ethno, and graphy. Put simply, this method deals with the narration of experiences from the perspective of the self (auto) by locating them within specific cultural (ethno) boundaries and articulated through written discourse (graphy). Autoethnographic inquiry, the author goes on, vindicates the role of one's identities and positioning in shaping knowledge, and establishes dialogue "with the

32 For legal reasons, the specific dates are not indicated.

33 Sykes, 5. 
situatedness of one's experiences, rather than suppressing them." ${ }^{\prime 34}$ Broadly speaking, this is a relatively new research method that enables the transformation of individuals as they engage in deep reflection about phenomena around them. According to Jones (2013):

... autoethnography is not simply a way of knowing about the world; it has become a way of being in the world, one that requires living consciously, emotionally, reflexively. It asks that we not only examine our lives but also consider how and why we think, act, and feel as we do. Autoethnography requires that we observe ourselves observing, that we interrogate what we think and believe, and that we challenge our own assumptions, asking over and over if we have penetrated as many layers of our own defenses, fears, and insecurities as our project requires. It asks that we rethink and revise our lives, making conscious decisions about who and how we want to be. And in the process, it seeks a story that is hopeful, where authors ultimately write themselves as survivors of the story they are living. ${ }^{35}$

This method is widely used today in several fields, such as anthropology, sociology, and education, and it has multiple variations. ${ }^{36}$ Autoethnography combines cultural analysis through narrative accounts, and personal data becomes primary data in the research process. Some techniques used include research journal writing, memorandums, e-mails, and the experiences of other researchers to triangulate the author's incidents with those of others, etcetera. ${ }^{37}$ Although autoethnography as a research method is a relatively recent asset, it is presently at the forefront of academic discussions in many fields, including, besides education, "counseling, psychology, sociology, the arts, and other spheres." ${ }^{38}$ It is also true that the method

34 Canagarajah, 260.

35 Quoted by Custer, 10.

36 Brent E. Sykes, "Transformative Autoethnography: An Examination of Cultural Identity and Its Implications for Learners," Adult Learning 25, 1 (2014): 3-10. DOI: https://doi. org $/ 10.1177 / 1045159513510147$

37 Sykes, 6.

38 Custer, 10. 
has limitations and has sparked a good deal of controversy; however, one of its greatest advantages lies in its potential to verbalize professionals' own experiences as they perceive them in situ, rather than, say, letting outsiders recount them through their own subjectivized interpretations.$^{39}$ Lastly, autoethnographers often take either of these two routes in the formal depiction of their analyses: They could use evocative autoethnography, which includes a detailed narration of relevant events, or else opt for analytical autoethnography, which "engages directly with theories and research findings." ${ }^{40}$ Drawing from Canagarajah's insights, I have resolved to use a combination of the two, with some prevalence of the latter to make sense of the CIs in light of theory which readers might already be familiar with (i.e., CT).

As for the data collection process, it was carried out over the course of nine months from February to November in the time frame referred to earlier in this section. Since I often found myself grappling with many obstacles in professional praxis, I decided to keep written records of critical events as a basis for preparing a systematic account of them in the future. In many ways, the methods used here resemble those of regular classroom ethnographies, with the slight difference that they led me to an eventual transformation in the way I understood language instruction. This transformation, which I present and theorize on below, makes up the core of autoethnographic research.

\section{Critical Incidents ${ }^{41}$}

The following incidents took place at a public high school in Costa Rica. ${ }^{42}$

39 Canagarajah, 261-2.

40 Canagarajah, 261.

41 This section includes a shortened version of the three CIs this article is based on. A full-length version is available in the CILAP conference proceedings (see footnote 1).

42 The State-financed Ministry of Public Education (MEP) has been the official organism in charge of the public education system since 1870. For more information, see: Presidencia de la República [de Costa Rica]. "Informe Nacional sobre el desarrollo de la Educación en Costa Rica" (2007) 5. 


\section{Critical Incident 1: “¿Es que me da flojera!”}

One Monday morning in February, as I was giving instructions for a small-group writing activity, a student I'd never seen before came into the classroom, dragging his backpack behind him. He threw himself on an empty seat in one of the front rows, rested his head against the chair, and stared at me defiantly. Noticing the class had gone numb, I questioned the student: "What's your name, Sir?" "Michael [fictitious]," he replied, disdainfully. "Would you happen to have a last name?" I inquired. But he wouldn't reply. He buried his head in his hands and closed his eyes, as if ready to fall asleep. "Listen, Mr. ... whatever your last name may be," I grumbled, "I don't know what brings you here, but whoever you are, you certainly have no right to enter as if you owned the classroom. This is an academic space and you must abide by the rules of institutional conduct." He went on to explain that he had been sent to eighth grade because the authorities had assumed that he would pass a make-up test. It turned out, he explained, that he did not pass the test and now he was being moved back to seventh grade. The newcomer then said he was the son of someone influential in the high school, and that English meant nothing to him because his stepfather was a U.S. American expat who had taught him "the ins and outs of the language." I told him that I did not care how much English he claimed to know, and that in my class no one could afford to shoot his mouth off and claim to be a Mr. Know-It-All. In the end, I decided to let him stay, under the condition that during the break we would go to the principal's office to have a word on his enrollment status and, most importantly, on his misbehavior.

Noting that the class had begun to have a good time seeing me struggle with the newcomer, I decided to put an end to the story by giving instructions on the activity that students had been about to begin before the class was interrupted. Everyone seemed to be working well, except the new student. On asking him why he had not joined any of the groups, he looked at me, and scornfully cried: " $E$ Es que me $d a$ 
flojera!" [I don't feel like it; it's a drag]. The class burst into laughter and, from then on, the class became chaotic. I ended up giving the student a minus-ten-percent ticket on rude behavior, warning him that if he went on like that he would get another minus-ten in his final Student Behavior Score..$^{43}$ But he still refused. So I gave him another minus-ten-percent ticket and warned him that yet another one would mean his almost failing the Student Behavior Score. I got him to sign both tickets and join a group, but he refused to complete the activities assigned. I decided to stop insisting on the minus-ten rhetoric because things could get even worse than they already were. The class came to an end and we headed straight into the principal's office, where the principal said the student had gone to the wrong classroom and that from then on, he would attend another teacher's class.

Letters went back and forth because the student's parents appealed the case, and we ended up filing only one ticket. What troubled me, though, was not the removal of the ticket; nor was it the issue with his parents complaining, or the many letters I had written or the meetings I had had to attend. What haunted me was my inability to deal with the case without having to resort to rules and regulations. I thought back about the long way I had come to graduate as a teacher, and especially about my research activity, which meant nothing in the critical situation I faced on that Monday morning. In my mind resonated, like an awful sound, the words: "es que me da flojera ... I don't feel like it; it's a drag... it's a drag."

\section{Critical Incident 2: Could I Borrow a Pair of Scissors?}

When I learned about the high indices of suicide attempts in that school, I simply could not believe it. During a teachers' meeting the story came up about a student who, in the past four months, had tried to kill herself nine times. The story went that the student had a complicated background: intra-family violence, single motherhood,

43 Known as nota de conducta in Costa Rica's public education system, this is a score given to students for their behavior. 
poverty, and many others. Another story was told about a ninth grader whose access to restrooms had to be restricted and closely supervised because she would try to cut her veins every time she would get a chance alone. The school counselor reported that this student had to follow a strict wrist-checking protocol every morning to show that no suicide attempts had occurred the day before, when she was out of school. Naturally, I panicked! And I panicked even more upon realizing that the two students mentioned were in my class! The meeting went on like this. While it was not meant to discuss suicide attempts in principle, we teachers ended speaking about it for nearly four hours, going off the topic from time to time only to tell about cases of student drug addiction and upcoming police visits to the high school.

That day I left the meeting feeling miserable. "What could I possibly do if I saw one of these students taking out a razor blade and cutting her wrists in my own classroom?" Too melodramatic, maybe; "but, what if... what if...?" I went on. I was suddenly pulled out of my meditations by the awareness that I was a member of the Assessment Board, and that frequently I was asked to leave my class for some time to attend last-minute meetings to deal with urgent issues. Three days later, as I feared, I was requested to attend one of those pop-up meetings. When I came back into the classroom, I was perplexed by the mess: papers, candy wrappers, pencil shavings... scattered all over the floor. Students were euphoric. Lunch time was close. They were probably worried that, as was usually the case, by the time they got to the school's dining hall, they would find a long queue and therefore would have to swallow their meal in five minutes before the next class began (if they were lucky enough to make it before the bell rang).

As I tried to bring the class back to order, a student came up to me and said (in Spanish): "Mr. Sevilla, could I borrow a pair of scissors from Jessica [fictitious name]?" I was about to say “yes" when I heard some students scream in unison: "Don't let her; please don't let her...." By the look on their faces I needed not know more. This was the student under close supervision in restrooms that they had talked 
about in the meeting three days before. And there she was, on her way to getting a pair of scissors and cut her wrist before everybody's eyes. And there was I, on my way to great legal trouble. Off the top of my head, it only occurred to me to tell her: "Hey Karla [fictitious name], drop it with the scissors thing. You're supposed to be working on the exercises I assigned, not cutting out little figures. Back to your seat, please!" A long, uncomfortable silence invaded the classroom. We all knew what she was up to, and we all knew we had escaped it by a hair's breadth.

\section{Critical Incident 3: The Skills or the Test?}

The last incident occurred during a forty-minute eleventh grade class, towards the end of July. I was already rushing with the school calendar because eleventh graders in Costa Rica finish off before the other grades do so that they get time for intensive preparation before the National Exit Examinations (NEE). ${ }^{44}$ I had devoted the first half of the class to working on the pronunciation of key vocabulary which students needed for a reading comprehension activity. The other half was assigned to reading a text and answering reading comprehension questions. Right before the end of the class, one student complained (in Spanish): "Mr. Sevilla, we won't have time to finish reading before the bell rings; why do we always waste time on other activities?" I explained that it was my responsibility to teach beyond the English NEE. But other students backed him up. To settle the matter, I promised I would give their claims a thought, but made sure they knew I was not comfortable reducing education to a test. Later in the day I talked to a colleague about the incident, and he did not hesitate to agree with the students: "I see where you're coming from, but in eleventh grade you simply don't have time to fool around with oral activities and such," he said. Shortly after, I heard the principal address the issue at a meeting. He said that, in the end, an eleventh-grade teacher

44 Pruebas de Bachillerato, as they are known in Spanish. 
at the MEP is evaluated exclusively by how many students pass the National Exit Examinations.

In the end, I gave in. Time was limited and I had to agree that the students were not actually ready for the English NEE. The question"the skills, or the test?"- had no room in my mind anymore, though I would still wonder what these students had been learning in the past four years. For the next three months or so, my classes focused exclusively on reading comprehension exercises, trying to help students build strategies to survive the test, doing the unthinkable to get a good promotion. I had made all that effort, however, just to find out that more than $40 \%$ of students failed the National Exit Examination. In the eyes of the system, these results meant that I was a fraud as a teacher. Only some years later would I learn from other colleagues that what most eleventh grade teachers do is make sure the students who take the English NEE will not jeopardize their reputation, even if that means that some (or many) students fail the course in the regular school year so that they do not even have a chance to take national exit exams.

\section{Discussion}

Before examining these three incidents, let us look into the origins of Complexity Theory, its essentials, and its relation to education and, in particular, to language teaching and learning, ${ }^{45}$ keeping in mind that this is only a brief review of CT in order to analyze the CIs; a fuller examination of this theory can be found in the references provided in this article. CT arose from chaos theory, a theory that first gained renowned popular attention in the natural sciences and which in turn extended into the social sciences given its potential to explain seemingly

45 Keith Morrison, "Complexity Theory and Education," APERA Conferences 2006, Hong Kong (2006): 1-12. 
chaotic phenomena from a scientific perspective. ${ }^{46}$ While studying weather prediction in 1960, meteorologist Edward Lorenz realized that apparently disorganized data showed common patterns which could meaningfully explain the development of certain processes. Analysis of those data enabled researchers to conclude that small weather changes in one city could generate massively devastating effects in other, distant cities. This phenomenon was popularized as the butterfly effect or sensitive dependence. ${ }^{47}$ From then on, as Bechtold pointed out (1997), chaos theory began to be understood as "a system theory that attempts to understand the behavior of nonlinear, unpredictable system." 48

Drawing from chaos theory, complexity theory acknowledges the chaotic nature of life and conceives reality as impossible to fathom through quantitative mechanisms. It also acknowledges the importance of details, rejects theories of cause and effect, and sheds light on language acquisition and instruction. ${ }^{49}$ Given its skepticism towards cause-effect approaches to research, this theory is concerned with explaining, rather than with enforcing theoretical precepts for classroom application..$^{50}$ In the teaching of English as a Second or Foreign Language (ESL/EFL), CT suggests that since all systems are flexible, adaptable, and complex, the language curriculum should never be a fixed entity, but rather a blueprint for teachers to use, adapt, and customize to their own local needs. ${ }^{51}$ In some countries, such as the Republic of Malawi, policy analysts have realized that educational policies rarely translate neatly into predicted outcomes, and that,

46 Happy M. Kayuni, "Chaos-Complexity Theory and Education Policy: Lessons from Malawi's Community Day Secondary Schools," Bulgarian Journal of Science and Education (BJSC) 4, 1 (2010): 5-31.

47 Kayuni, 7.

48 Quoted in Kayuni, 8.

49 See: Nasrin Hadidi Tamjid, "Chaos/Complexity Theory in Second Language Acquisition," Novitas-ROYAL 1, 1 (2007): 10-17.

50 Hassan Soleimani and Farnaz Farrokh Alaee, "Complexity Theory in CALL Curriculum in Foreign Language Learning," International Journal of Applied Linguistics \& English Literature 3, 3 (2014): 19-25. DOI: https://doi.org/10.7575/aiac.ijalel.v.3n.3p.19

51 Soleimani, 20. 
instead, "real change and new structures are found in the very chaos they [managers or policy makers] try to prevent." ${ }^{52}$ In others, this realization remains a far cry on the part of stakeholders, teachers, parents, and students alike. At the methodological level, CT can be used in studying language acquisition by retrospectively analyzing the language changes that have taken place in students. ${ }^{53}$ That is, instead of testing a hypothesis derived from previous generalizations about a specific system (e.g., an ESL class), CT analysis is about connecting the dots to identify the multiple causes that have led to a certain effect, such as an increase in test scores or a student's loss of motivation towards a subject. If this new way of understanding language acquisition research should generate uncertainty in the research community, Diane Larsen-Freeman years ago observed that "the problem of an unstable system is not a problem after all - that a characteristic of a complex, nonlinear system is persistent turbulence." ${ }^{54}$ Put simply: Let us not panic about complexity; let us seek in it the answers we cannot reach through linearity.

Generally speaking, it appears that the applicability ofCT to education and applied linguistics remains rather narrow and, in Morrison's words, "spasmodic and piecemeal" 55 in comparison to the acclaim it enjoys form the natural sciences, anthropology and economics. The reasons could be linked at least in part to the fact that CT suggests steps towards localness and with this a deviation from the linear, topdown programming traditionally endorsed by our education systems. As Morrison explains:

[...] complexity theory suggests a movement towards bottom-up development and change, local and institutional decision-making

52 Qtd. in Kayuni, 7.

53 Diane Larsen-Freeman and Lynne Cameron, "Research Methodology on Language Development from a Complex Systems Perspective," The Modern Language Journal 92, 2 (2008): 200-2013. DOI: https://doi.org/10.1111/j.1540-4781.2008.00714.x

54 Diane Larsen-Freeman, "Chaos/Complexity Science and Second Language Acquisition," Applied Linguistics 18, 2 (1997): 141-165 (159). DOI: https://doi.org/10.1093/applin/18.2.141

55 Morrison, 1. 
on education, a re-assertion of child-centredness and experiential, exploratory learning, a rejection of tight prescription and linear programming of teaching and learning and a move towards nonlinear learning and their curricular derivatives. Complexity theory emphasises the process rather than the content of learning, as the constituents of relevant and enduring curriculum content are uncertain (Doll, 1993). Emergence and selforganization require room for development; tightly prescribed, programmed and controlled curricula and formats for teaching and learning, and standardised rates of progression are anathema to complexity theory. ${ }^{56}$

In addition to this, skepticism has emerged because CT is still an evolving concept, posing new dilemmas such as the degree to which its applicability would require new epistemological framings to current scientific undertakings. Rejection has further intensified as CT motivates two types of differences: "differences within complexity theory itself [and] differences in the interpretation of [its] implications within social theory." 57 After admitting that he is a "sympathetic skeptic," Morrison criticizes CT saying: "It is a fascinating and alluring theory, but is it a siren song?"58

It is not the goal here to take sides on the general scope of CT. However, since the paper seeks to analyze phenomena that cannot be measured using positivistic methodologies, the lines ahead will present a theoretical analysis of the CIs in light of CT.

In the first incident, we see a conflict involving discipline and class management. The clash emerges as two rationalities collide in two divergent domains: the student's reasons to be in the classroom and the teacher's ideas of how a student should behave. Equally important, the word flojera (literally, "laziness") and the student's behavior as a whole become vital to our discussion since this may

56 Morrison, 6.

57 Sylvia Walby, "Complexity Theory, Systems Theory, and Multiple Intersecting Social Inequalities," Philosophy of the Social Sciences, 37, 4 (2007): 449-470 (456). DOI: https://doi. org/10.1177/0048393107307663

Morrison, 10. 
be linked to a more general attitude of laziness in current society, of which the student is but a small representation. In other words, perhaps this student's behavior was simply the tip of the iceberg in a system that in general has promoted this type of behavior and failed to give teachers their place. But in CT this is, at best, only half of the story. It is also quite likely that I, also as part of a larger, pre-configured social scheme, ended up resorting to the power that by default is conferred to teachers from the moment they enter a classroom. The question inevitably arises as to whether there were other alternatives to the conflict, as to whether my choice of the words ("you must abide by the rules of institutional conduct") and the like made matters even worse. The case also calls for reflection on the fact that many teachers are, indeed, responsible for the respect they have lost before students. But then again, the circular paradox of the chicken and the egg comes in posing the questions: Who is to be blamed for the respect they have lost? Is it teachers themselves, the universities they graduated from, or society at large? To answer these questions acceptably, we require extensive research on how well universities are preparing English teachers, on the type of education children are receiving at home, and ultimately on whether "laziness" is an isolated symptom in students or rather the standard in all of our social strata (including curricular authorities in our education system), among other variables that might do better justice to the phenomenon's complexity.

With regard to the second CI, little is needed to show that certain issues are outside the scope of classroom methodology and good teacher preparation. Suicide attempts, complex family records, pop-up meetings, dining problems, and other institutionally-bound problems make teaching one of the most intricate professions. When one thinks back about all the emphasis given to methodological preparation in universities, conferences, and teacher-training events, one cannot help but conclude that we all may be too fooled by standardization philosophies of education. Ian Tudor makes the point that methodology (as dictated by outside experts) and pedagogical 
reality are almost polar concepts. The former, he claims, is theoretical precept; the latter is the interaction of methodology with context as it is experienced in the classroom. This implies that methodology should be locally situated, and that it cannot be assumed as always corresponding with pedagogical reality because classrooms are part of a larger socio-geo-cultural setting which shapes the dynamics of teaching and learning. ${ }^{59}$ From this viewpoint, in incident 2 the first step towards working out solutions would be to adjust methodology to the ethos of teaching/learning where the event occurred. In other words, it would be necessary to reject, as Soleimani proposes, "any pre-set curriculum" and become active negotiators in real time and in the real teaching context. ${ }^{60}$ This would not solve all the issues outlined in the CI. However, being honest about classroom dynamics would put us on the path toward solutions.

In the third CI, we notice a conflict that is both internal and external. It was internal because I felt it was my duty to teach beyond the English NEE. In my view back then, teachers should be agents with instructional freedom, not just "skilled technicians who dutifully realize a given set of teaching procedures in accordance with the directives of a more or less distant authority." ${ }^{\prime 61}$ Inner struggle was intensified by a greater sense of responsibility on seeing that the MEP's syllabus itself demanded the covering of other topics beyond reading comprehension. On the external side, my standpoint was contrary to students' rationalities, to those of my fellow colleague, and ultimately to the high school principle, who in turn might have been worried about the institution's reputation before MEP authorities. From the lens of CT, this clash of forces illustrates the discrepancy between the collective system (students, my colleague, the principal and some regional authorities), my own professional rationalities, and the theoretical precept as dictated in the national English syllabus.

59 Tudor, 132-133, 135.

60 Soleimani, 20.

61 Tudor, 17. 
Overall these three incidents exemplify typical failure in our public education system: failure to manage students' discipline, failure to deal with factors outside the scope of methodological control (suicide attempts and the like), and failure to teach for the four language skills and to prepare students to pass the national exit exam. ${ }^{62}$ Inevitably, at this point some crucial questions arise about such failure; for instance: Who is supposed to have failed? Is it I, for not having been able to help students pass the English NEE; and if so, am I not falling victim of a serious contradiction? Am I not reducing English teaching to a test with which I myself bluntly disagree? Is it the fault of the students, for not doing their share of the work? Is it their former English teachers, for not equipping them with the right tools to succeed? Is it institutional authorities, for abiding by the law of experts' precepts? Is it the public education system, for rejecting localness and embracing standardization? Is it society as a whole, with its chaotic nature and evolving realities that make it an ordeal to reach for quality language instruction? Or is it none, or all of the above? These are the type of questions whose uncertainty we can only endure through the lens of CT, and whose answers can only be pursued if English teaching is accepted for what it is rather than for what policy makers, in the illusion of inexperience, ${ }^{63}$ want it to be. While teachers are certainly part of the collective systems we have already discussed, and which $\mathrm{CT}$ insists on, a series of issues make teaching at the MEP one of the most complex experiences imaginable. They include, but are not restricted to, the following:

1. Curricular obstacles (such as the disparity between instruction and assessment): Teachers are asked to teach the four skills but are usually limited to assessing only reading comprehension,

62 This is my own autoethnographic operationalization of failure, and it goes without saying that the entire system is a failure. Readers are invited to accept, reject, or criticize this operationalization based on their own theoretical and personal standpoints.

63 I am referring here to the possibility of a lack of experience with real classrooms and with real chaos as illustrated in at least two of the incidents addressed in this article. 
vocabulary and grammar skills (an exception to this is, of course, bilingual high schools), and the mismatch between proposed syllabus and classroom reality.

2. Missing too many classes: Currently there are at least two week-long assessment periods each quarter (six a year), and teachers cannot cover content to be assessed during the week before assessments. More classes are missed due to holiday celebrations, pop-up school conferences, meetings with the Board of Assessment, union conferences (one week per year), strikes, and other unexpected events.

3. Resources and logistics (such as large classes, lack of basic resources): Some instructors must teach in halls, under trees, and even in churches, or collect money and work at night to patch holes in the school driveways.

4. Psycho-socio-cultural factors (such as discipline problems, students' intra-familiar violence, suicide attempts, dysfunctional families): In addition, we must consider the ethos of teaching and learning - students used to rote memorization, unsupportive parents, and dogmatic institutional authorities.

5. Social inequality: The fifth annual report on the state of Costa Rican education, regarding high schools' academic performance inequalities in Costa Rica, has concluded that they can be related to internal system inequalities such as the high school's modality, class schedule, and geographical location, as well as to demographic and socioeconomic factors and available resources. ${ }^{64}$ The report goes on to stress that, contrary to popular belief, high school performance in Costa Rica can be linked more to students' social backgrounds than to the type and quality of education received. ${ }^{65}$ Along the same lines, findings contradict circulating discourse that private

64 Programa Estado de la Nación en Desarrollo Humano Sostenible, Estado de la Educación Costarricense: Resumen. (San José, Costa Rica: Prolitsa, 2015) 1-52.

65 Programa Estado..., 37. 
schools offer better education and therefore help students attain better scores on standardized tests such as the $P I S A^{66}$ tests. The study found that when students come from similar socio-economic contexts, students from public and private high schools achieved similar scores.

Evidence from this last challenge supports the claim that understanding the dynamics of our educational system goes beyond pointing fingers and scapegoating teachers for our students' failure. In this sense, CT offers a working framework to start embracing English teaching as it is, with all its risks, imperfections, and difficulties. And whereas the answers to these issues are hard to suggest, it is my understanding so far that we need to stop viewing teaching as a controllable laboratory of commandments set in stone. Nothing is more illusory than forcing ourselves to believe that methodological rigor is the key to quality education, that diversity can be accomplished through standardization, and that numbers determine failure or success. Once this realization is reached, we will be in a better position to think about more sublime intentions such as encouraging teacher-produced research, making primary schools and high schools bilingual, bringing assessment and instruction together, and many of other nicely decorated ideas that sound good in principle but which will never be a possibility unless we change current views on teaching - especially on language teaching. I would like to take on Tudor's claim that more attention should be paid to failure in classrooms as "...difficulties or even failures can teach us more about the reality of language teaching than easy and unanalyzed success. ${ }^{967}$

66 Programa Estado..., 39-40. The Programme for International Student Assessment (PISA) evaluates students' reading comprehension, math and science performance.

67 Tudor, 135. 


\section{Concluding Remarks}

This autoethnographic research has sought to offer a glimpse into the complexities of English teaching in Costa Rica's public high schools, and how they are linked to a series of elements that are for the most part outside teachers' control. Taken together, the findings add up to the claim that classrooms are dynamic, unpredictable sites of struggle where multiple rationalities coexist and conflict, and which need to be understood as such before random decisions are made. For the macro field of applied linguistics, findings are relevant in at least three different ways: (a) they expand the bulk of literature on the subject studied, (b) they call for more attention to the complexities of EFL, and (c) they open room for reflection and future directions in research. In so doing, CT comes along as a framework for a clear understanding of the complex systems that converge in and beyond the boundaries of a language classroom.

In his Nobel Prize for Literature Acceptance Speech, Algerian writer Albert Camus pronounced the following words: "By definition [the writer] cannot put himself today in the service of those who make history; he is at the service of those who suffer it. ${ }^{968}$ By extension, we could suggest that the researcher today cannot put himself at the service of those who write policies, but at the service of those who deal with them on a daily basis, including fellow teachers, students, parents, authorities and society as a whole. Future research should therefore take the form of grassroots studies that examine the voices of the immediate actors in the teaching enterprise. This can be achieved by running more autoethnographic, autobiographical and narrative inquiry, bringing more bottom-up investigation into the research equation. Quantitative methodologies can also be promoted within this spectrum, but then again, only insofar as they seek to understand

68 Quoted by: Annalisa Oboe and Shaul Bassi, Experiences of Freedom in Postcolonial Literatures and Cultures (London: Routledge, 2011) 135. 
rather than to prescribe, only if they serve the noble purpose of gathering sufficient empirical evidence to forge research-based solutions.

Naturally, I am aware of counterarguments that my thesis might arouse. Opponents could argue that my CIs are not necessarily representative of all realities that take place in a public high school English classroom. And they would be generally right, I must agree. However, that very claim is an invitation to believe that they can, indeed, be the realities of many instructors whose voices happen to get lost in the limbo of everyday struggle and frustration. They may also claim that my solutions are unrealistic or too simplistic, but this is a limitation that can only be overcome through further research, discussion, and reflection.

To the critical eye, it may well appear that this research is but an excuse to speak about the difficulties of English teaching at the MEP. Well, let it be an excuse then. Let it be an honest excuse to problematize a subject that otherwise would go unnoticed in the milieu of positivistic research and traditional academia. With that said, I can only hope that the curricular authorities and stake-holders will not ignore the contribution which in good faith I have tried to make. I am also hopeful that at the very least my stories will resonate in the ears of teacher-researchers who, like me, have felt their best intentions frustrated by the entanglements of our public education system. 